\title{
An Analysis Of Moral Values In Burnett's Little Lord Fauntleroy Novel
}

\author{
Desfika Beti Utami ${ }^{1}$, Restu Arini ${ }^{2}$ \\ English Education Department, Faculty of Teachers Training and Education, Mercu \\ Buana University Yogyakarta \\ email: 1desfika.utami@gmail.com, ${ }^{2}$ restuarini@gmail.com
}

\begin{abstract}
This study deals with a novel entitled Little Lord Fauntleroy written by Frances Hodgson Burnett. The objectives of the study are: (1)to describe Cedric's personality in the novel and (2)to reveal the moral values from Cedric's personality in the novel. The study employed library study and descriptive qualitative analysis method. The data of the study are from the novel and other supporting documents. Based on the analysis, the writer found two things: firstly, Cedric is characterized as a boy who has good personalities such as honest, kind-hearted, friendly, humble, wise, sympathetic and responsible. Secondly, the moral values that can be taken from the novel are honesty, kindness, hospitality, modesty, wisdom, empathy and responsible.
\end{abstract}

Keywords: Moral Values, Little Lord Fauntleroy, Burnett, Cedric, Novel

\section{Introduction}

Moral derives from the Latin 'mos' which means attitude and habits. This attitude based on the determination of right and wrong. Value means standard that used to define something and regarded as a conventional. In other word, moral value is standard of attitude that based on the determination of right and wrong which is regarded by those who make the standard of moral.

Esteban as quoted by Adisusilo (1990, p57) states that "Moral values are universal truths which man holds to be good and important; they are the ethical principles which he struggles to attain and implement in his daily life. They are the ideals which transcend all time and space; those which are valid for all men regardless of race or religion; the ones which unite strangers, families, nation all of humanity - with God." Moral values can also be reflected in literary works. It gives readers a reflection about life and additional appeal for the novel itself. One novel that contains rich of moral value is a novel written by Burnett entitled Little Lord Fauntleroy.

Burnett has played an important role in the emergence of novel as a respected literary form. She has contributed powerfully to determine the form of English novel, especially in Victorian Era. According to Bradburry (1973, p.32) the typical species of the novel in England is the socio moral novel, or the novel of manners and morals. The prime theme of which is the 
ethical conduct of man in society is relatively stable and secure. The English novels also express a particular species of moral realism. Therefore, analyzing an English novel will give better achievement in understanding the values of life as reflected in that novel. Based on the above explanation and facts, the writer intended to dig deeper on the main character of the novel to find out more moral values as life lessons. To ease the analysis, two research problems are formulated as follows: 1. How is Cedric's personality depicted in the novel? 2. What are the moral values that can be taken from Cedric's personality in the novel?

Before analyzing the novel, the first step is studying, selecting and collecting the chapter of the novel. Actually, when the researcher reads each chapter of the novel, automatically the researcher knows the intrinsic social problem of the novel. It will ease the researcher to get the data (Yohanes Eko Rubiyanto, 2016).

\section{Methodology}

The object of this study is a novel entitled Little Lord Fauntleroy written by Frances Hodgson Burnett. The novel was originally published by Charles Scribner's Sons in 1886. The version that the writer uses in this study was published by HardPress Publishing and it contains of 209 pages divided into 15 chapters. The primary data for this study are Cedric's words, phrases, sentences, and images in the novel. The secondary data for the study are taken from supporting documents. This research is using descriptive qualitative method. The writer uses objective approach and the combination of some theories to analyze the data taken. The objective approach is an approach that focuses the analysis on the intrinsic elements of a literary work.

\section{Findings and Discussion}

\section{Characters}

There are only some characters, both major and minor ones, in the novel that make the story flows. The first character is Cedric Eroll or "Cedric", a young boy who is inherited the title of an "Earl" from his grandfather. The second character is Cedric's mother or "the dearest" as Cedric calls her. The third character is the Earl of Dorincourt who is Cedric's grandfather. The fourth character is Mr. Hobbs. He is a grocer and has a grocery store in New York, in the same street where Cedric lives. More characters in the novel are such as Mary, 
Dick, Benjamin, Thomas, Havisham, and Dawson.

\section{Short Description on Cedric}

Cedric is a seven-year-old boy who lives only with his mother in the crowded city of New York, America. Cedric is half American and halfBritish. His father was an Englishman and his mother is a beautiful American woman. Cedric is a handsome boy with curly yellow hair. "wearing a short white kilt skirt, and a big white hat set back on his curly yellow hair, he was so handsome and strong and rosy that he attracted every one's attention," (p.7). Despite of his age, Cedric has point of view like a grown man. He likes to talk almost anything from daily lives, Cedric's friends and also politics. It seems that Cedric is more mature than his age. Cedric maturity can be seen in the following quotation:

\section{Cedric's Personalities}

In this part, the researcher would like to elaborate Cedric's personality. The elaboration of Cedric's personality would be important later when the researcher talks about the moral value that can be taken from the novel because the whole novel story is dominated by Cedric's life story. The writer would like to elaborate more about Cedric's personalities in the next section.

\section{Cedric is an Honest Boy}

Cedric is an honest boy. He never lies to anyone in his life. He always tells the truth whenever he speaks to anyone. The evidence of Cedric honesty can be seen in the following quotation in which Cedric talks to Mr. Hobbs about earl and aristocracy. From the conversation above both Cedric and Mr. Hobbs have negative assumptions and ideas about earl and marquises. They think that earl and marquises are tyrants and rude. In fact, Mr Hobbs has sworn himself that he will not let any earl and marquises to enter his store and sit on his crackerbarrels. This idea makes Cedric a little hesitant to tell Mr. Hobbs that actually he will become an Earl. However, Cedric tries to be honest to Mr. Hobbs. Cedric's honesty can be seen in the following quotation.

\footnotetext{
"You said," he proceeded, "that you wouldn't have them sitting 'round on your cracker-barrels." “So I did!" returned Mr. Hobbs, stoutly. "And I meant it. Let 'emtry it--that's all!"

“Mr. Hobbs," said Cedric, “one is sitting on this box now!"
} 
Mr. Hobbs almost jumped out of his chair.

"What!" he exclaimed.

"Yes," Cedric announced, with due modesty; “_I_ am one--or I am going to be. I won't deceive you." (p.14)

\section{Cedric is a Kind-Hearted Boy}

Cedric lives with a mother who always put kindness above everything so that Cedric grew up with the same value inside his soul. When Cedric socialized with others, he always makes goodness to others. He is always kind to others especially those who live in poverty. When Cedric sees a poor old lady who sells apples for living, he and his friends decide to buy apple from her in order to help her. By doing this, he hopes the old lady would take the money and can use it for living. The way Cedric makes kindness to the old lady can be seen in the following quotation:

She's a hundred, I should think, and yet she is out there when it rains, even. I'm sorry for her, and so are the other boys. Billy Williams once had nearly a dollar, and I asked him to buy five cents' worth of apples from her every day until he had spent it all. That made twenty days, and he grew tired of apples after a week; but then--it was quite fortunate--a gentleman gave me fifty cents and I bought apples from her instead. You feel sorry for any one that's so poor and has such ancient lin-lenage. She says hers has gone into her bones and the rain makes it worse." (p.30-31)

In the conversation it can be seen that Cedric feels sorry for the old lady. He sees that the lady is so poor so that she is very thin and cold makes her shiver. Cedric buys apples from her so that she can buy something to make her more comfortable.

\section{Cedric is a Friendly Boy}

Cedric is also a friendly boy. He makes many friends in his life. In fact, Cedric's charm makes him gets many friends. It is from the following quotation:

... his nurse would come home and tell his mamma stories of the ladies who had stopped their carriages to look at and speak to him, and of how pleased they were when he talked to them in his cheerful little way, as if he had known them always. His 
greatest charm was this cheerful, fearless, quaint little way of making friends with people (p.6).

Since he is small Cedric is very friendly to anyone. Whenever he speaks he could attracts many people to be his friends. It is admitted by Cedric's nurse when she tells Cedric's mother how pleased people were when they speaks to Cedric. In his young age, Cedric has many best friends. One of his best friends is Mr. Hobbs, a groceryman. Mr. Hobbs is quite old and he owns a grocery in the corner of the street in New York.

\section{Cedric is a Humble Boy}

Humble is defined as showing or having a low or modest opinion of one's own importance or not proud (Hornby, 1995:582). Being humble means not to be proud of one's self. In the novel Cedric is characterized as a humble boy. Since from the very beginning of the novel Cedric is personalized as a humble boy, it can be seen from the following quotation in which he humbly tells Mr. Hobbs that he will become a member of a noble family.

"Who is your grandfather?" he asked.
... "I couldn't easily remember

it, so I wrote it down on this,"he said. And he read aloud slowly: “John Arthur Molyneux Errol, Earl of Dorincourt.' That is his name, and he lives in a castle--in two or three castles, I think. And my papa, who died, was his youngest son; and I shouldn't have been a lord or an earl if my papa hadn't died; and my papa wouldn't have been an earl ifhis two brothers hadn't died. But they all died, and there is no one but me,--no boy,--and so I have to be one; and my grandpapa has sent for me to come to England."

... "Ah," remarked Cedric, with a sigh, "I never thought I should have to be an earl then!" (p.17\&19).

From the quotation above, it can be seen that Cedric is too humble in telling mr. Hobbs that he is going to be a little lord, a member of a noble family in Britain.

\section{Cedric is a Wise Boy}

Cedric in the novel is also depicted as a wise boy. Wise means having or showing experience, judgment, and knowledge that leads one to respond sensibly to a particular 
situation. Cedric is already wise sincehe was very young. It can be seen from the way he treats his mother during hard days in their family.

Since his papa's death, Cedric had found out that it was best not to talk to his mamma about him. When his father was ill, Cedric had been sent away, and when he had returned, everything was over; and his mother, who had been very ill, too, was only just beginning to sit in her chair by the window. She was pale and thin, and all the dimples had gone from her pretty face, and her eyes looked large and mournful, and she was dressed in black.

He felt her arms tremble, and so he turned his curly head and looked in her face. There was something in it that made him feel that he was going to cry (p.1).

The quotation shows that Cedric sees that his mother is sad because her husband, Cedric's father, is ill. He is wise enough not to bother his mother who is still sad and even get sick. At that time Cedric's father is passed away and the family is in mourning situation. The way Cedric treats his mother is such mournful situation shows that although Cedric is still a small boy, he is able to think wisely for the sake of his mother.

\section{Cedric is a Sympathetic Boy}

Cedric is also a sympathetic boy. He is often showing sympathy to others, especially people around him. In the beginning of the novel, Cedric shows his sympathy toward his own mother.

Then, little as he was, he understood that his big, handsome young papa would not come back any more; that he was dead, as he had heard of other people being, although he could not comprehend exactly what strange thing had brought all this sadness about. It was because his mamma always cried when he spoke of his papa that he secretly made up his mind it was better not to speak of him very often to her, and he found out, too, that it was better not to let her sit still and look into the fire or out of the window without moving or talking (p.2). The quotation clearly shows that Cedric 
sympathize for his mother's sadness. He knows that his mother is very sad because his father died. Whenever Cedric talks about his father, his mother starts to cry. That is why Cedric decides not to talk about his father anymore in front of his mother. He does not want his mother to cry and feel sad. That is why Cedric can be said as a sympathetic boy.

\section{Cedric is a Responsible Boy}

Cedric is also a responsible boy. It can be seen in his daily life. He is always responsible for things that become his responsibility. The first fact that shows it is as follows:

"I don't like it," he said once as he was having one of his almost venerable talks with the lawyer. "You don't know how much I don't like it; but there are a great many troubles in this world, and you have to bear them. Mary says so, and I've heard $\mathrm{Mr}$. Hobbs say it too. And Dearest wants me to like to live with my grandpapa, because, you see, all his children are dead, and that's very mournful. It makes you sorry for a man, when all his children have died--and one was

killed suddenly." (p.50).

The quotation shows that actually Cedric does not want to live with his grandfather because he only wants to live with his mother. However, since he loves his mother very much and feels responsible for her, he obeys his mother to live in his grandfather's house. Cedric also has other kinds of responsible, that is he becomes the only descendant left from the Earl of Dorincourt family. If his father is still alive, he will be the next Earl. However, since his father was passed away, the responsibility to become the Earl and to continue the family honor is on Cedric's shoulder.

\section{Moral Values in the Novel}

There are many moral values of the novel that can be taken as life lesson. The moral value is a good things that can be taken as our own life lesson to make our life better.

\section{Cedric Teaches Us about Honesty}

Cedric in the novel teaches the readers and all of us to be honest. In his life, Cedric is always honest to anyone, especially to his mother, his grandfather and Mr. Hobbs. Honesty is a good thing to do. It can make people happy and feel trusted. Whenever we tell the truth in the 
most honest way, people will also feel respected that they entrusted something important.

Based on the theory of Conscientiousness, Cedric's honesty also brings good moral value because honesty is not against moral law. Cedric conducts his actions without conflicting his desires or inclinations. Based on theory of Character Traits, being honest is also considered as good moral value. Cedric has good traits that is useful and valuable, that is why the moral lesson taken from his personality is a good moral value. Based on theory of Motives, Cedric's honest brings good moral value because the act of being honest is not harming other people. Cedric has good motives in being honest such as to please his mother, the Earl and his friends.

\section{Cedric Teaches Us about Kindness}

Cedric in the novel also teaches the readers to be kind to others. Being kind is a good moral value. It teaches us that whenever we expect people to be kind to us, we should also be kind to others. By being kind to others, people will see us as good people too and they will not hesitate to make friends with us.

$$
\text { The theoryof Actual }
$$

consequences of the Act also agrees that to be kindhearted is a good moral value because it brings good consequences. When we kind to others, they will be kind too. In the novel, because Cedric is always kind and generous to other people, the people respect and also love Cedric. The theory of Conscientiousness also considers being kindhearted is a good moral value. The theory says that is the moral value is not overcome by desires or inclinations, then the moral value good. Being kindhearted is a good moral because it is the right to do. Based on the theory of Useful Character Traits, the moral value of to be kindhearted is a good moral value because Cedric has good traits. $\mathrm{He}$ is a good character in the novel. Theory of motives also agrees that doing kindness to other people is a good moral value. In the novel Cedric is a kind-hearted boy and he has no intension to harm people in doing the kindness. He does so many kindness because he wants to make other peoplehappy.

\section{Cedric Teaches Us about Hospitality}

Other moral value that can be taken from the novel is being friendly to anyone. According theory of Actual Consequences of the Act, being friendly will bring many good consequences, such as having more friends and building family-like bond to other people. It means being friendly can be 
said as good moral values. Seen from theory of Conscientiousness, the moral value of being friendly is also a good moral value because it does not break the moral law and it is the right thing to do. The same judgment comes also from theory of useful Character Traits. The moral value of being friendly is a good moral value because it reveals good morality, useful and valuable too. Whereas, seen from theory of motives, being friendly is a good moral value because it has good intension and also does not harmanyone.

\section{Cedric Teaches Us about Modesty}

In the novel Cedric is not too proud with his new title as a lord and a member of a noble family. He does not show up his wealth. In fact, Cedric uses his wealth to help other people. By being humble to anyone we will make more friends and have less enemies. The theory Actual Consequences of the act views humble personality as a good moral value. It is because humbleness brings good consequences. When one is humble, he or she will be accepted in the society. Theory of Conscientiousness also agrees that being humble is a good moral value because it is the right thing to do. Being humble also respects the moral law. According to theory of Useful Character Traits, being humble is a good moral value because Cedric bear good traits or personality. Any moral value that comes from his personality is considered good. Base on Motives, being humble is always a good moral value. The dominant motives in being humble is to make good things to other people and not to harm them.

\section{Cedric Teaches Us about Wisdom}

By reading the novel the reader also can learn how wise Cedric is. It gives valuable moral value, that is being wise. Based on Actual Consequences of the Act theory, to be wise a good moral value because it brings so many good consequences such hinder problems, help other people to solve problems and many more. The same judgment comes also from the theory of Conscientiousness. It says that being wise is a good moral value because it does not break the moral law and does not harm other people. The theory of Useful Character Traits also agrees that being wise is a good moral value. Since Cedric is always behave well in the novel and he has good character. Seen from theory of motives, being wise is a good moral value because it has good intension and motive.

\section{Cedric Teaches Us about Empathy}


Being sympathetic is also a moral value that can be taken from Cedric's life. Being sympathized to others is a good thing to do. It shows how good we are and how we care for other. To show sympathy is not always by giving things, money or any other physical products. We can sympathize by giving attention, listening to others and even by saying "Hi" to other people. The theory of Actual Consequences of the Act is surely agree that being sympathetic to other is a good moral value. Sympathetic action often brings good consequences. The same judgment also comes from theory of Conscientiousness. It says that being sympathetic is a good moral value. Being sympathetic is a right thing to do.

Moreover, being sympathetic is closely related to one's personality. Cedric has good personality, that is why the moral value taken from his story is always considered as good moral value. Moreover, seen from the motive, being sympathetic is a good motive because Cedric is always have good intension

\section{Cedric Teaches Us about Responsibility}

Responsibility is an important thing in life. It is also one of moral values that can be taken from Cedric's life. Responsibility is something that we should do all the time. By keeping our responsible people will trust in us and in the future, the trust will bring many benefits for us. To be responsible is a good moral value because it always builds good outcomes. By being responsible to anything we do, other people will put trust on us, respect and make us their friend. Inline to the judgment of the theory of Actual Consequences of the act, Conscientiousness is also agree that responsibility is a good moral value because it is the right thing to do. According to theory of Useful Character Traits, being responsible is a good moral values because it comes from Cedric's personality that is considered as good character in the story. Additionally, being responsible usually has good motives. When a person is able to take the responsibility then he should have good motive.

\section{Conclusion}

Based on the analysis, the researcher concludes; first, Cedric is characterized as a boy who has good personalities. His personalities are such as an honest boy, kind-hearted, friendly, humble, wise, sympathetic and responsible. These personalities makes Cedric have a lot of friends. He even 
makes friends with the tyrant Earl. The second conclusion is the moral values that can be taken from the novel. The first moral value that can be taken is being honest. The second moral value is being kind to others. The third moral value is being friendly to anyone. The fourth moral value from the novel is being humble. The fifth moral value is being wise. The sixth moral value is being sympathetic to others and the last moral value that can be taken from the novel is being responsible.

\section{Bibliography}

Abrams, M. H. 1981. The Glossary of Literary Terms. New York: Holt Rinehart and Winston Inc.

Adisusilo, S. J. R. 1990. Pembelajaran Nilai Karakter Konstruktivisme dan VCT sebagai Inovasi Pendekatan Pembelajaran Afektif. Jakarta, J: PT Raja Grafindo Persada.

Barnet, Sylvan. 1986. Literature for Composition. London: Scott, Foresman and Company

Bergman, David, \& Epstein, D. Mark. 1987. The Health Guide to Literature. Lexington: D.C. Heath and Company.
Bradburry, A. 1973. Women and Money in Eighteenth-Century Fiction. Oxford: Oxford University Press.

Dudley, Robin. 2011. Morality and Literature [and] Graphic Novels: A CriticalIntroduction and Sally Killingsworth. London: Bibliobazaar.

Forster, E. M. 1975. Aspects of the Novel and Related Writings. London: Edward Arnold

Guth,Hans. P. 1981. The Literary Heritage. Massachusetts: DC Heath

Henkle, Roger B. 1981. Reading the Novel. New York: Harper \& Row Publisher, Ltd

Hollingshead, Greg. 2011. Short Story Vs Novel. (retrieved from http://www.greghollingshead.c om/essays/short-story-vsnovel. June 9,2016)

Hornby,As. 1995. Oxford Advanced Learner's Dictionary. Oxford: Oxford University Press.

Hudson, William Henry. 1958. An Introduction to the Study of Literature. London: George G. Harrap.

Katherine, L Carlson. 2010. "Little Lord Fauntleroy and the Evolution of American Boyhood". The Journal of the History of 
Childhood and Youth. Vol 3, Number 1, Winter 2010. pp.39-64.

Kirk, Ashley. 2012. The Importance of Historicism and Context in Literature. Online (Retrieved from http://www.ashleykirk.com/2012/11/theimportance-of-historicismand.html, on June 6,2016)

Koesnobroto, S. B. 1988. The Anatomy of Prose Fiction. Jakarta: Departemen Pendidikan dan Kebudayaan.

Kohlberg, L. 1982. The Philosophy of Moral Development: Moral Stages and the Idea of Justice. San Francisco: Harper \& Row. Mc Mahan, Elizabeth, Robert Funk, and Susan Day. 1988. Literature and the Writing Process. Newyork: Routledge, Chapman \& Hall. Inc.

Miliawati, Mega., Adiana Meilia., Basuki, Imam. 2012. A Study

On The Main Character's Personality Development in F.H. Burnett's Little Lord Fauntleroy. Unpublished Thesis. Jember: Jember State UniversityMilligan, Ian. 1983. The Novel in English: An introduction. London:

Macmillan Press, Ltd. Moody, H.L.B. 1971. The Teaching of Literature with Special Reference to Developing Countries. London: Longman Group Ltd,

Murphy, M. J. 1972. Understanding Unseen. London: George Allen and Unwin, Ltd.

Nugroho, Vito Adi. 2016. Book review of Little Lord Fauntleroy Written By Frances Hodgson Burnett. Unpublished Thesis. Semarang: Diponegoro University

Perrine, Laurence. 1974. Literature: Structure, Sounds, and Sense. New York, NY: Harcout Brace Jovanovich Inc.

Pickering, James H. \& Hoeper, Jeffrey D. 1986. Literature. New York: Macmillan Publishing Company.

Rohrberger, Mary \& Samuel H. Woods. 1971, Jr. Reading and Writing about Literature. New York: Random House, Inc.

Sinclair, William Angus. 1956. Socialism and the Individual. New York: Oxford University Press. 
Syarifah, Nur. 2015. The Translation of

$$
\begin{aligned}
& \text { a Novel "Little Lord } \\
& \text { Fauntleroy" into Indonesian. } \\
& \text { Unpublished Thesis. Jakarta: } \\
& \text { Gunadarma University. }
\end{aligned}
$$

Teeuw, A. 1984. Membaca dan Menilai Sastra. Jakarta: Gramedia

Webster, Mariam. 1994. Collegiate Dictionary. $\quad$ Springfield: Springfiled, MA.
Wellek, Rene and Austen Warren. 1965.

Theory of Literature. New York: Harcourt, Brad and World, Inc.

Wellman, Carl. 1975. Moral and Ethics. Illinois: Scoott, Foresman and Company

Yohanes Eko Rubiyanto. (2016). Social Class Conflict Presented In "The Kite Runner" Novel Based On Marxism Theory, JELE, 2, 125-134. Retrived From http://ejurnal.mercubuanayogya.ac.id/index.php/jele/article/vie $w / 228$ 